Agro-Science Journal of Tropical Agriculture, Food, Environment and Extension Volume 15 Number 2 May 2016 pp. $54-58$

ISSN 1119-7455

\title{
DETERMINANTS OF MARKETING EFFICIENCY OF YAM MARKET IN UMUAHIA NORTH LOCAL GOVERNMENT AREA OF ABIA STATE, NIGERIA
}

\author{
Offor*, E.I., Nse-Nelson, F.A. and Asokome, F. \\ Department of Agricultural Economics, Michael Okpara University of Agriculture, \\ Umudike, Abia State, Nigeria \\ Corresponding author's email: offorevelyn53@gmail.com
}

\begin{abstract}
The study analyzed the determinants of yam marketing in Umuahia North Local Government Area of Abia State, Nigeria. A two stage sampling technique was used to select yam marketers for the study. Stage one involved the purposive selection of two major yam markets due to the activities of yam marketing in the markets. The second stage involved the random selection of fifteen yam marketers from each of the two markets to give a total of thirty (30) yam marketers for the study. Data collected were analyzed using simple statistics such as mean, frequency and percentages. Profit function approach was used to realize objective one, marketing margin, and marketing efficiency formulas were used to achieve objectives two and three. Also a schematic diagram was used to show the flow of yam from the producers to the consumers. Multiple regression analysis was used to analyze the determinants of marketing efficiency while the constraints that militated against yam marketing were analyzed using mean, frequencies and percentages. The results show that yam business in the study area is profitable. A rate of return on investment of 1.23 was obtained and marketing margin and marketing efficiency of 25.5\%and 23.16\% respectively were obtained. The coefficient of educational level and marketing experience were significant and positively related to marketing efficiency. Transportation cost was significant, but negatively related to marketing efficiency. The most important constraints that militated against yam marketing include: high cost of transportation and inadequate credit facilities. The study therefore, recommends that the yam marketers should form cooperative societies to increase their access to credit facilities, and government should provide good road network system to reduce transportation cost.
\end{abstract}

Key word: cost, returns, yam marketing, Umuahia North

\section{INTRODUCTION}

Yam is a tuberous crop that belongs to the family of Dioscoreaceae. It is an energy-giving food that is widely accepted. A thick tropical vine-tuber, it is native to warmer region hemisphere and popular in Africa, West Indies, parts of Asia and South Central America (Mignonuma et al., 2003; CGIAR, 2006).

Nigeria which is a tropical country is one of the highest yam producers of yam in the world. Recent world data showed that Nigeria accounts for $65 \%$ of the total world production; about 38 million metric ton which is cultivated on 2.9 million-ha cultivated area of land in 2012 and valued at $\$ 7.75$ billion (Odigbo, et al., 2015).

Yam is considered an important energy giving staple food in Nigeria as in other parts of the tropics. It constitutes an important source of food and income and plays a major role in the socio-cultural life of many smallholder households. It ranks second after cassava among roots and tubers (Odigbo et al., 2015). In the West African sub-region, yam has the potential to alleviate poverty and ensure food security among rural producers, traders, processors and consumers (Chukwu and Ikwelle, 2000). Its tubers can be eaten in different forms, ranging from roasting, boiling, frying, pounding into paste as well as processing into yam flour which can be eaten with soup. Its peels can also be processed into livestock feed. Hence it is considered an important staple to combat food insecurity in areas where it is cultivated.

Marketing is all efforts made to ensure the movement of agricultural commodities from farmers to consumers. Understanding the determinants and 
performance of a marketing system of agricultural produce is imperative in order to ascertain its status. A well-developed marketing system compliments farm production efforts and helps it to realize its desired goals through the provision of time, place, form and possession utilities. Olukosi et al. (2005) opine that a well-developed marketing system enhances the pace of economic development by encouraging specialization, generation of foreign exchange, development of an exchange economy, provision of income and employment opportunity for marketing agents. Marketing agent perform wide range of functions. These functions include, assembling, processing, grading, and transportation. Assembling is the collection of product in order for them to be available in large quantity to attract buyers. Processing is transforming the raw products into forms most suitable as required by the ultimate consumers (Smith and Quelch, 1993). Grading is the selection and grouping of yam into their various sizes (Kohl and Uhl 1985). Transportation involves the movement of products from surplus places to deficit areas in order to create place utilities. The marketing of yam involves exchange points and the number of exchange points depends on the distance between yam production area and that of consumption. The sequence of flow at times is from farmers' compound to the village market then to the urban market. The various routes through which yam passes from point of production to the ultimate consumer is the marketing channel (Reddy et al., 2004). The entire yam production and marketing chain offers vast employment opportunities to many people. Therefore, a well-developed marketing system is expected to result in an efficient marketing of its products. An efficient market is that in which the marketing costs are sufficient enough to cover the value added through utility creation. Obasi and Amaechi (2013) has it that an efficient marketing system is well capable of moving commodities from place of production to areas they are needed in a manner that is beneficial to the producers, marketing intermediaries and consumers.

Despite the contribution of yam to human diet, its production and marketing are in the hands of smallholder farmers who are resource poor and as such, cannot afford all it takes to boost the sector. These farmers are constrained with diverse problems that range from production to marketing. However, research on yam has focused more on pre-production issues to the neglect of post-harvest issues like marketing, storage and consumer demand. Robert et al. (2012) stated that in developing countries, more emphasis is usually placed on policies to increase food production with little or no consideration given to the efficient distribution of the food produced in a manner that will enhance increased productivity. Food marketing by farmers and traders, mostly in the immediate post-harvest period, usually involves huge costs in Nigeria. For yam, lowering the costs through efficient marketing system may be as important as increasing yam production. Hence the broad objective of the study was to examine the determinants of marketing efficiency of yam in Umuahia North Local Government Area (LGA) of Abia State. Specifically, the study examined: (i) cost and return of yam marketing (ii) marketing margin, (iii) marketing efficiency, (iv) the channel of distribution, as well as (v) estimated the factors that affect marketing efficiency and lastly identify the constraints that militated against yam marketing in the study area.

\section{MATERIALS AND METHODS}

The study was carried out in Umuahia North LGA of Abia State, Nigeria. Umuahia North is located at latitude $5^{\circ} 32^{\prime} \mathrm{N}$ and longitude $7^{\circ} 29^{\prime} \mathrm{E}$. The area has a land mass of $245 \mathrm{~km}^{2}$. It has a population of 220,660 people (NPC, 2006). The people of Umuahia North are mainly Igbo speaking people and farming is one of their major occupations. Two-stage sampling technique was used to select thirty yam marketers. In stage one, purposive sampling was used to select two major yam markets based on the level of yam marketing activities in the markets. The markets are Orie-Ugba and Obani. Stage two involved the random selection of fifteen yam marketers from each of the markets to give a total of thirty (30) yam marketers for the study. The data for the study were collected with the aid of structured questionnaire in late April and early May 2015.

Objective I which investigated costs and returns from yam marketing was realized using profit function. Profit $($ Net Return) = Total Revenue (TR) minus Total Marketing Cost (TMC). Objective II which was to estimate marketing margin (MM) was achieved using the marketing margin model (Isitor et al. 2005):

$$
(M M)=\frac{\text { Selling Price-Purchasing Price }}{\text { Selling Price }}
$$

Objective III which was to estimate the marketing efficiency (ME) of yam was achieved using marketing efficiency ratio as also applied by Olukosi and Isitor (1990) and Ozougwu (2002):

$$
M E=\frac{\text { Value addition by marketing (net return) }}{\text { Total marketing }} \text { (ii) }
$$

Objective IV on the marketing channel was realized using schematic diagram. Furthermore, objective $\mathrm{V}$ which estimated the determinants of marketing efficiency was analyzed using multiple regression model stated in its implicit form. The model is specified as follows: 
$Y=F\left(X_{1}, X_{2}, X_{3}, X_{4}, X_{5}, X_{6}, X_{7}, X_{8}, X_{9}\right)$

$\mathrm{Y}=$ Marketing Efficiency (percentage)

$\mathrm{X}_{1}=\operatorname{Sex}(1=$ male, $0=$ female $)$

$\mathrm{X}_{2}=$ Marital status $(1=$ married, $0=$ single $)$

$\mathrm{X}_{3}=$ Marketing association $(1=$ yes, $0=$ no $)$

$\mathrm{X}_{4}=$ Mode of operation $(1=$ fulltime, $0=$ part time $)$

$\mathrm{X}_{5}=$ Age (years)

$\mathrm{X}_{6}=$ Educational level (years)

$\mathrm{X}_{7}=$ Household size (number of persons)

$\mathrm{X}_{8}=$ Marketing experience (years)

$\mathrm{X}_{9}=$ Transportation cost (Naira)

Finally, the sixth objective was realized using mean, frequency and percentages.

\section{RESULTS AND DISCUSSION}

Weekly Average Net Return, Marketing Margin and Marketing Efficiency of Yam Marketing in Umuahia North LGA of Abia State, Nigeria

The weekly average net return, marketing margin and marketing efficiency are presented in Table 1 . The data show that the average purchasing price for yam was $\$ 66.76$ per $\mathrm{kg}$ and its selling price was $\$ 83.82$. The net return from the business was $\$ 12,135.66$. Marketing margin and marketing efficiency of 25.6 and $23.16 \%$, respectively were obtained. These results imply that the business was profitable; however, the marketing efficiency ratio (23\%) indicates inefficiency. The findings are similar to those of Robert et al. (2012) who reported a marketing margin of $27.4 \%$ for yam marketing in four districts of Ghana namely Techiman, Atebubu, Ejura- Sekyedumasi and Nkwanta. The business was profitable even though the yam marketing among producer-sellers was found to be inefficient. A return on investment of $\$ 1.23$ obtained further stressed the profitability of the business since a return of 1.23 accrues to the investor for every 1.00 invested in the business.

The Schematic Diagram of the Flow of Yam from Production Area to Consumption Point in Umuahia North LGA of Abia State

The marketing channel of yam from point of production to consumption is shown in Figure 1. The marketing channel for yam was a two stage channel system. The wholesalers got their supply from the producers in the middle belt of Benue and Lafia. They supply to the retailers and sometimes sell directly to the consumers. The retailers hawk the yam tubers in wheel borrows or sell in stores to final consumers. Due to the distance between the point of production and consumption the retailers and consumers could not obtain direct supply from producers.
Table 1: Weekly average net return, marketing margin, marketing efficiency of yam in Umuahia North LGA of Abia State, Nigeria

\begin{tabular}{ll}
\hline Items & Price/kg \\
Purchasing price & 66.76 \\
Selling Price & 83.82 \\
Marketing Cost & 52409.09 \\
Total Return from sales & 64544.75 \\
Net Return & 12136.87 \\
Marketing Margin & $25.55 \%$ \\
Marketing Efficiency & $23.16 \%$ \\
Return on investment & 1.23 \\
\hline
\end{tabular}

Sourced: Survey Data 2015

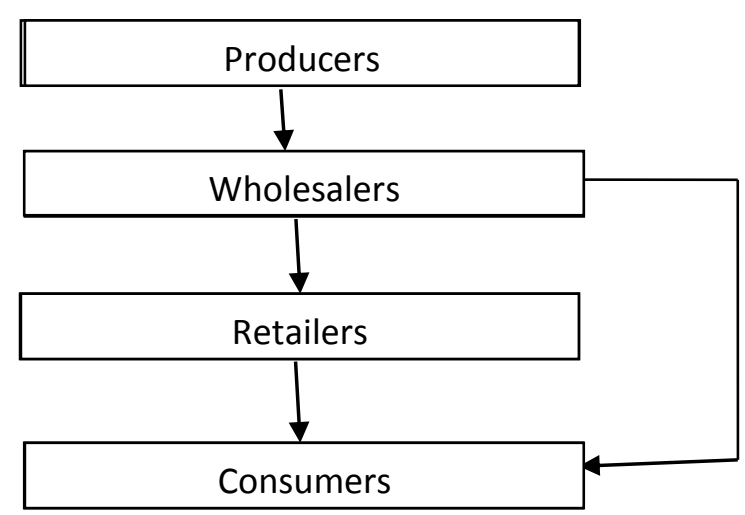

Figure 1: A schematic marketing channel of yam

Determinants of Yam Marketing in Umuahia North LGA of Abia State, Nigeria

The results in Table 2 show the ordinary least square regression analysis of the determinants of marketing efficiency among yam marketers in the study area. The double $\log$ functional form was chosen as the lead equation based on high $\mathrm{R}^{2}$ value and other significant variables that agree with apriori expectation. The $\mathrm{R}^{2}$ value of 0.6173 implies that about $62 \%$ variability in marketing efficiency was explained by the independent variables. The F-ratio value was highly significant at $1 \%$ probability level, indicating best of fit .The coefficient of gender was positively signed and highly significant at $1 \%$ level indicating that ,the male yam marketers were more efficient than their female counterparts. This is contrary to the findings of Robert et al. (2012) who found that females dominated the business of yam marketing. The coefficient of educational level was positive and was significant at $5 \%$ probability level. This implies that an increase in the educational level of the marketers leads to corresponding increase in their marketing efficiency. Educational attainment gives additional intellectual capital stock which may in turn leads to increase potentials for skills acquisition in 
Table 2: Determinants of marketing efficiency of yam in Umuahia North LGA of Abia State, Nigeria

\begin{tabular}{lllllc}
\hline Variables & \multicolumn{1}{c}{ Parameter } & \multicolumn{1}{c}{ Linear } & \multicolumn{1}{c}{ Exponential } & \multicolumn{1}{c}{ Double } & Semi-log \\
\hline Constant & $\mathrm{B}$ & $362.5(0.71)$ & $2.7137(1.96)^{*}$ & $1.4553(0.49)$ & $1201.87(1.05)$ \\
Gender & $\mathrm{X}_{1}$ & $128.780(1.38)$ & $0.4039(1.59)$ & $0.3593(3.36)^{* * *}$ & $14.085(1.31)$ \\
Marital status & $\mathrm{X}_{2}$ & $1.2130(0.02)$ & $0.1106(0.75)$ & $0.1319(1.000)$ & $.9188(0.20)$ \\
Marketing association & $\mathrm{X}_{3}$ & $-58.810(-0.54)$ & $-0.2197(-0.75)$ & $-0.2832(-1.05)$ & $-87.9840(-0.85)$ \\
Age & $\mathrm{X}_{4}$ & $-8.8700(-1.09)$ & $0.0079(0.36)$ & $-0.5819(-0.07)$ & $-477.48(-1.59)$ \\
Educational level & $\mathrm{X}_{5}$ & $9.9300(0.20)$ & $0.1906(1.42)$ & $0.67200(2.85)^{* *}$ & $26.1904(0.16)$ \\
Household size & $\mathrm{X}_{6}$ & $-22.0970(-0,880)$ & $-0.0619(-0.91)$ & $-0.4573(-1.32)$ & $-138.77(-1.04)$ \\
Marketing experience & $\mathrm{X}_{7}$ & $16.450(1.510)$ & $0.0272(0.92)$ & $0.4421(2.14)^{*}$ & $178.989(2.26)^{*}$ \\
Transportation cost & $\mathrm{X}_{8}$ & $-0.0005(-0.010)$ & $0.0001(0.27)$ & $-0.3012(-2.24)^{*}$ & $92.6599(1.80)^{*}$ \\
Mode of operation & $\mathrm{X}_{9}$ & $159.360(13.60)$ & $0.4514(1.41)$ & $0.3898(1.35)$ & $138.312(1.25)$ \\
$\mathrm{R}^{2}$ & & 0.2763 & 0.5368 & 0.6173 & 0.4674 \\
$\mathrm{R}^{-2}$ Adjusted & & $3.14 * * *$ & 0.4361 & 0.5341 & 0.3516 \\
\hline
\end{tabular}

marketing (Laper et al., 2003). The coefficient of marketing experience was significant and had a positive relationship with marketing efficiency. This implies that, as marketing experience increases, marketing efficiency also increases. Okoye (2011) stated that marketing experience helps to reduce proportionately the transaction cost of participants which in turns increases marketing efficiency. The coefficient of transportation cost was negatively signed and significant at $10 \%$ level of probability. This implies an inverse relationship, as transportation cost increases, marketing efficiency reduces. Location of the marketers in respect of potential markets is an important factor in encouraging marketer to increase their sales (Makhura, 2001).

\section{Constraints that Militated against Yam Marketing in the Study Area}

Table 3 shows the constraints that militated against yam marketing in the study area. Perishability, bulkiness and high cost of transportation were the major constraints the markers indicated hence they were ranked first. Price fluctuation ranked second among the constraints yam marketers indicated as problem in the study area. This could be due to the seasonality in yam production and supply. The marketers stated that at harvest, yam tubers are cheaper but prices increase at off season which affects the quantity purchased. More so, poor access roads and inadequate credit availability were the third factors that militated against yam marketing while, inadequate storage facilities and seasonality of yam were the least constraints identified by the marketers that confront them in the business.
Table 3: Constraints to yam marketing in Umuahia North LGA of Abia State, Nigeria

\begin{tabular}{|c|c|c|c|}
\hline Constraints & Frequency & Percentage & Rank \\
\hline Perishability & 30 & 100 & 1 \\
\hline $\begin{array}{l}\text { High cost of } \\
\text { transportation }\end{array}$ & 30 & 100 & 1 \\
\hline Bulkiness & 30 & 100 & 1 \\
\hline Price fluctuation & 28 & 93.3 & 2 \\
\hline $\begin{array}{l}\text { Inadequate } \\
\text { credit facility }\end{array}$ & 26 & 86.6 & 3 \\
\hline Poor access road & 26 & 86.6 & 3 \\
\hline Storage facilities & 12 & 40.0 & 4 \\
\hline $\begin{array}{l}\text { Inadequate } \\
\text { market store }\end{array}$ & 12 & 40.0 & 4 \\
\hline $\begin{array}{l}\text { Seasonality } \\
\text { of yam }\end{array}$ & 8 & 26.0 & 5 \\
\hline
\end{tabular}

\section{CONCLUSION}

The study was able to estimate the determinants of yam marketing efficiency in Umuahia North LGA of Abia State. The results showed that the business was profitable with a rate of return on investment of 1.23. This implies that, for every 1 invested in yam marketing, a return of 1.23 accrues to the investor. However the marketing system was inefficient. Among the factors that affected the marketing efficiency were sex, educational level and marketing experience. These had positive relationship with marketing efficiency and were all significant at 1, 5 and $10 \%$ levels of significance, respectively. The coefficient of transportation cost was negatively signed. This implied that as transportation increases, marketing efficiency decreases. 


\section{RECOMMENDATIONS}

From the findings of the study the followings were recommended: More people should be encouraged to venture into yam business. Marketers should come together and form cooperatives in order to increase their access to credit facilities. Government should provide good road network to reduce transportation cost and hence increase the net return of the marketers.

\section{REFERENCESS}

Adegeye, A.J. and Dittoh, J.S. (1982). Essential of Agricultural Economics ( $2^{\text {nd }}$ ed.) Impact Publishers Ltd, Ibadan, pp. 35-41

Bain, J.S. (1968). Industrial Organization (2 ${ }^{\text {nd }}$ ed.), John Wiley and Sons, New York pp.74-80

CGIAR (2006). Output Improvement in the Tropics. Consultative Group Int'l Agricultural Research No. 13. CGIAR of United Nations

Crammer, G.L. and Jenson, C.W. (1991). Agricultural Economics and Agribusiness. John Wiley and Sons, New York, pp. 51-54

Chukwu, G.O. and Ikwelle, M.C. (2000). Yam: threats to its sustainability in Nigeria. PALAWIJA NEWS, The CGPRT Centre Newsletter, 17(1). pp.20-25

FAO (2001). Food and Agricultural Organization Year Book Trade 5, pp. 35-59

FAO (2006). Food and Agricultural Organization data base www.fao.org.accessed 21/10/2007

Folayan, J.A. and Oguntade, A.E. (2010). Performance of yam wholesales marketing in Efon Alaaye of Ekiti State. International Journal of Economic Development Research and Investment 1 (2\&3), 2-9

Kohl E.S. and, Uhl, J.N. (1985). Marketing of Agricultural Products. Macmillan Publication Company, New York, pp. 210-215

Laper, M.L., Holloway, G. and Ehui, G. (2003). Polari options promoting market participation among smallholder livestock producers: a case study from Philippines Food Policy, 28, 189-211

Makhura, M.T. (2001). Overcoming Transaction Cost Barriers to Market Participation of Small-holder Famers in the Northern Province of South Africa. PhD Dissertation, University of Pretoria, Pretoria pp. 182
Mignouna, H.O, Abana M.M. and Asiegbu, R. (2003). Harnessing Modern Biotechnology for Tropical Tuber Crops Improvement. G.U. Publication, Abuja, Nigeria, pp. 98-102

NPC (2006). National Population Commission, Abuja, Nigeria

Obasi, I.O. and Amaechi, E.O. (2013). Efficiency of poultry marketing in Owerri Municipal Imo State. Research Journal of Agricultural and Environmental Management, 2(8), 197-201

Odigbo, B.E., Ogbidi, J.B. and Ewa, E.A. (2015). A situation analysis study of yam distribution strategies of farmers in Boki Local Government Area of Cross River State. Nigeria Journal of Economic and Sustainable Development, 6 (14), 190-201

Okoye, B.C. (2011). Analysis of Market Participation among Small-holder Cassava Famers in Response to Transaction Cost in South Eastern Nigeria. PhD Dissertation. Michael Okpara University of Agriculture Umudike, Abia State Nigeria, 145 pp.

Olukosi, J.O, Isitor, S.U. and Ode, M.O. (2005). Introduction to Agricultural Marketing Price Principle and Application Living Books Series G.U. Publication, Abuja, Nigeria. pp. 75-79

Olukosi, J.O. and Isitor, S.U. (1990). Introduction to Agricultural Marketing Price Principle and Application. Living Books Series G.U. Publication, Abuja, Nigeria. pp. 68-72

Ozougwu, F.C. (2002). Analysis of Rice Marketing Margin in the Marketing Channel of Adani Rice in Uzo-Uwani Local Government Area. MSc Thesis, University of Nigeria Nsukka. 158 pp.

Reddy, S.S., Ram, P.R, Sastry, T.V.N and Devi, I.B. (2004). Agricultural Economics. Oxford and IBH Publishing CO.PVT. Ltd, New Delhi India, pp. 525-527

Robert, A., Fred, N., John-Eudes A.B., Kwasi, O., Simon, C.F., James, O.M. and Robert, C.A. (2012). Estimation of margins and efficiency in the Ghanaian yam marketing chain. Asian Journal of Agriculture and Rural Development, 2, (2), 226-234

Smith, N. and Quelch, J.A. (1993). Ethics in Marketing. Horne Wood Publication, III Irwin. pp. 62-65 